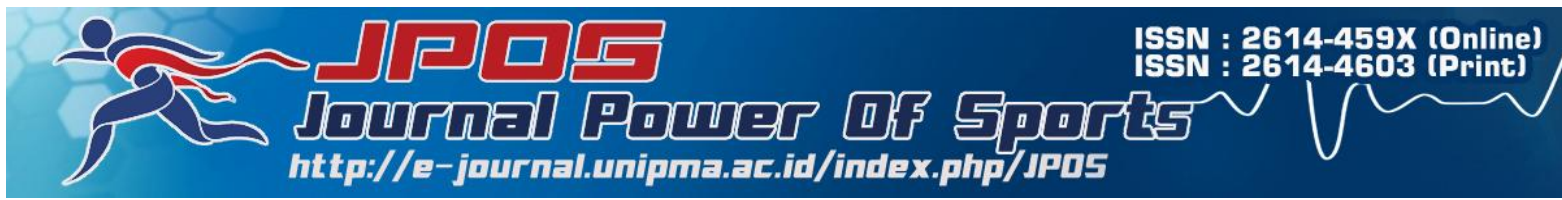

\title{
Pengaruh latihan lay up 6 tahap terhadap hasil lay up pemain putra usia SMP pada sekolah basket Smiling Java Boyolali
}

Pratama Dharmika Nugraha

Program Studi Ilmu Keolahragaan, Universitas PGRI Madiun, Indonesia

Email: pratama.dharmika@unipma.ac.id

\begin{abstract}
Abstrak
Tujuan penelitian ini untuk mengetahuai pengaruh latihan lay up 6 tahap terhadap hasil lay up pemain putra usia SMP pada sekolah basket Smiling Java Boyolali. Metode penelitian yang digunakan adalah eksperimen dengan desain penelitian one group pre-test and post-test design. Populasi pulasi pemain putra usia SMP pada sekolah basket Smiling Java Boyolali yang bejumlah 20 orang. Teknik pengambilan sampel menggunakan total sampling, jadi seluruh anggota populasi digunakan sebagai sampel. Jumlah anggota sampel 20 orang. Rata-rata peningkatan hasil lay up 3,9. Hasil dari uji-t menunjukan $t_{\text {hitung }}>t_{\text {tabel }}$ yaitu 16,25 > 2,09 maka $\mathrm{H}_{0}$ diterima. Jadi terdapat peningkatan hasil lay up setelah mendapat perlakuan.
\end{abstract}

Kata kunci : lay up; pemain putra; usia SMP.

\section{The effect of exercise lay up 6 stages on lay up players for junior high school basket ball players at Smiling Java Boyolali basket ball school}

\begin{abstract}
The purpose of this research is to know the effect of 6 layers lay up training on the lay up of junior high school boys at Smiling Java basketball school in Boyolali. The research method used is experiment with one group research design pre-test and post-test design. The population of junior high school boys at Smiling Java School amounted to 20 people. The sampling technique uses total sampling, so all members of the population are used as samples. The sample size is 20 people. Average increase in lay up 3.9. The result of t-test shows $t_{\text {count }}>t_{\text {table }}$ that is 16.25> 2.09 then HO is accepted. So there is an increase in lay up after treatment.
\end{abstract}

Keywords: lay up; man player; junior high school.

How To Cite : Nugraha, D. P. (2018). Pengaruh latihan lay up 6 tahap terhadap hasil lay to APA Style up pemain putra usia SMP pada sekolah basket Smiling Java Boyolali. JPOS (Journal Power Of Sports), 1 (1), 12-18. 


\section{PENDAHULUAN}

Olahraga merupakan bagaian dari komponen untuk membangun jati diri manusia yang sebenarnya. Di Indonesia olahraga juga menupakan suatu sarana untuk meningkatkan derajat bangsa di mata dunia. Jadi olahraga merupakan bagian yang tidak dapat dipisahkan dari kehidupan masyarakat di Indonesia. Salah satu olahraga yang digemari di Indonesia adalah olahraga bola basket. Peminatnya mulai dari pelajar SD / sederajat, SMP / sederajat, SMA / sederajat, mahasiswa, serta masyarakat umum dari berbagai kalangan.

Teknik permaianan dan peraturan permainan bolabasket memang tergolong rumit bagi yang belum terbiasa. Peraturannya bukan sekedar pelanggaran apabila terjadi kontak fisik atau foul, tetapi ada pula yang berhubungan dengan kesalahan teknik atau violation (Perbasi, 2010: 27). Permainan bola basket merupakan permainan untuk mencetak skor sebanyak-banyaknya pada ring lawan dengan durasi waktu 4 x 10 menit (4 quarter).

Cara mencetak skor pada parmainan bolabasket adalah dengan teknik lay up. Teknik lay up sering digunakan karena prosentase untuk menghasilkan skor lebih besar dibandingkan dengan shooting. Teknik shooting merupakan cara memasukan bola ke dalam ring dengan tantangannya adalah jarak, sedangkan lay up merupakan upaya memasukan bola sedekat mungkin dengan ring.

\section{Smiling Java merupakan suatu} wadah untuk manampung minat penggemar bola basket di Kabupaten Boyolali. Sekolah ini mengutamakan pembinaan bola basket pada tinggak pelajar, dengan harapan dapat memngembangkan potensi yang dimiki pelajar di Kabupaten Boyolali melalui olahraga bola basket.

Teknik lay up adalah tenik memasukan bola ke ring yang efektif, sebab dilakukan pada jarak yang sedekatdekatnya dengan basket atau keranjang (Imam Sodikun, 1992:64). Teknik lay up sampai saat ini semakin bervariasi, unsur yang perlu diperhatikan dalam teknik lay up ada beberapa macam, diantaranya langkah kaki, juluran tangan dan lompatan. Setiap pemain basket harus belajar dan bisa melakukan lay up dengan tangan kanan maupun tangan kiri, langkah kaki pun mengikuti juluran tangan saat melakukan teknik lay up.

Gerakan kaki saat melakukan lay up dengan melangkah satu kali deng posisi lutut agak ditekuk sehingga anda dapat segera melompat pada langkah kedua kemudian mengangkat lutut untuk saat melakukan lompatan (Hall Wissel, 2000:61). Lengan tangan, pergelangan tangan dan jari-jari harus lurus ke arah ring basket dan lepaskan bola dari telunjuk dengan sentuhan yang halus. Setiap pemain harus belajar melakukan lay up dengan tangan kanan maupun tangan kiri sehingga dapat menunjang permainan tim untuk memperoleh kemenangan. Ada beberapa hal penting yang perlu diperhatikan ketika melakukan gerakan lay up agar dapat dikuasai, yaitu: fase persiapan, pelaksanaan, dan follow through.

Metode latiahan yang digunakan merujuk pada metode belajar part and whole. Part-method atau metode bagian adalah metode yang diterapkan dengan cara memecah suatu pembelajaran menjadi bagian-bagian dan menggabungnya lagi setelah siswa berhasil menguasainya dengan tujuan untuk mempermudah siswa dalam memahami suatu pembelajaran (Hidir Firdaus, 2014:365). Whole-method atau metode keseluruhan adalah metode dengan penerapan pembelajaran yang dilakukan secara utuh keseluruhan dan dilakukan secara berulang-ulang sampai siswa paham dan menguasai betul materi yang diajarkannya (Hidir Firdaus, 2014:365). Jadi metode latihan part and whole adalah latihan yang dilakukan dengan memecah suatu rangkaian gerakan 
dan dilakukan secara berulang-ulang yang kemudian gerakannya dirangkai menjadi satu rangkaian gerakan secara utuh.

Gerakan lay up dimulai dari mendribble bola, melangkah, lompat, dan gerakan lanjutan. Rangkaian gerakan lay up tersebut dibagi menjadi 6 tahap. Gerakan pertama: bergerak satu langkah dan menjadikannya tumpuan untuk langsung melompat ke arah ring dengan tujuan memasukan bola, gerakan kedua: bergerak dua langkah dengan langkah yang kedua sebagai tolakan, gerakan ketiga: melakukan satu kali dribble kemudian melangkah dan melompat, gerakan keempat: melakukan 2-3 kali dribble dari garis three poin kemudian melangkah dan melompat, gerakan kelima: melakukan dribble dari seperempat lapangan kemudian saat mendekati ring melangkah dan melompat, gerakan keenam: melakukan dribble dari garis tengah lapangan kemudiaan saat mendekati ring melangkah dan melompat. Jadi latihan lay up 6 tahap adalah membagi latihan lay up menjadi 6 tahap berdasarkan jarak serta menggunakan teknik yang sesuai pada setiap jarak atau titik dimulainya gerakan lay up.

Komponen kondisi fisik sangat diperlukan dalam menunjang prestasi olahraga. Faktor kondisi fisik menjadi tuntutan di setiap cabang olahraga, karena kualitas kondisi fisik akan menunjang secara langsung terhadap kualitas gerak yang ditampilkan (M. Sajoto, 1995:8), berikut komponen kondisi fisik: (1) Kekuatan (strength), adalah komponen kondisi fisik seseorang tentang kemampuannya dalam mempergunakan otot untuk menerima beban sewaktu bekerja, (2) Daya Tahan (endurance), dalam hal ini dikenal dua macam daya tahan, yaitu: daya tahan umum (general endurance) kemampuan seseorang dalam mempergunakan sistem jantung, paru-paru dan peredaran darah secara efektif dan efesien untuk menjalankan kerja secara terus-menerus yang melibatkan kontraksi sejumplah otot-otot dengan intensitas tinggi dalam waktu cukup lama. Daya tahan otot (local endurance) adalah kemampuan seseorang dalam mempergunakan ototnya untuk berkontraksi secara terus-menerus dalam waktu yang relatif lama dengan beban tertentu, (3) Daya Otot (muscular power) kemampuan seseorang untuk mempergunakan kekuatan maksimum yang dikerahkan dalam waktu yang sependek-pendeknya. (4) Kecepatan (speed) kemampuan seseorang untuk melakukan gerakan berkesinambungan dalam bentuk yang sama dalam waktu sesingkat-singkatnya. (5) Daya Lentur (flexibility) efektifitas seseorang dalam menyesuaikan diri untuk segala aktifitas dengan penguluran tubuh yang luas. (6) Kelincahan (agility) adalah kemampuan seseorang mengubah posisi di area tertentu, (7) Koordinasi (coordination) adalah kemampuan seseorang mengintregasikan bermacam-macam gerakan yang berbeda ke dalam pola gerakan tunggal secara efektif, (8) Keseimbangan (balance) kemampuan seseorang mengendalikan organ-organ syaraf otot, (9) Ketepatan (accuracy) adalah kemampuan seseorang untuk mengendalikan gerakan-gerakan bebas terhadap sasaran. Sasaran ini dapat merupakan suatu jarak atau mungkin suatu objek langsung yang harus dikenai dengan salah satu bagian tubuh, (10) Reaksi (reaction) adalah kemampuan seseorang untuk segera bertindak secepatnya dalam menanggapi rangsangan yang ditimbulkan lewat indera, syaraf atau feeling lainnya.

Berdasarkan penjelasan tersebut dapat disimpulkan komponen kondisi fisik yang diperlukan untuk melakukan rangkaian gerakan lay up adalah kekuatan, kecepatan, daya ledak, keseimbangan, flesibilitas, koordinasi, dan ketepatan.

Masa adolesensi untuk perempuan 10 sampai 18 tahun, laki-laki usia 12 sampai 20 tahun (Lankor, 2007:105). Kriteria tersebut menunjukan bahwa siswa putera pada usia SMP berada pada masa adolesensi, karena siswa SMP biasanya 
berada pada kisaran usia 12 sampai 15 tahun. Menurut Sugiyanto dalam Lankor (2007:110) pertumbuhan dan perkembangan adolesensi dapat dijelaskan sebagai berikut: (1) Pertumbuhan fisik, pertumbuhan ukuran tubuh pada awalnya mengalami percepatan, kemudian melambat dan berhenti. Laki-laki cenderung menjadi relatif lebih tinggi dan lebih besar. Togok laki-laki relatif tumbuh lebih cepat dibanding kaki dan tangan, bahu melebar, dada makin bidang. Pinggul pada perempuan melebar dan membesar, buah dada membesar. Tipe tubuh individu semakin jelas. Perkembangan jaringan tubuh pada laki-laki semakin berotot, sedangkan perempuan semakin berlemak. Perubahan fisiologis, penurunan denyut nadi bazal. Terjadi peningkatan temperatur tubuh bazal. Tekanan darah sitolik meningkat. Peningkatan volume pernapasan, kapasitas vital, dan kapasitas pernapasan maksimum. (2) Perkembangan kemampuan fisik, perkembangan kemampuan fisik yang menonjol adalah kekuatan, kecepatan, ketahanan kardiovaskular. Laki-laki peningkatannya lebih besar dibandingkan perempuan. (3) Perkembangan kemampuan gerak, lakilaki mengalami perkembangan lebih besar dibanding perempuan. Selain itu laki-laki terus meningkat kemampuan gerak yang memerlukan kekuatan, kecepatan, kelincahan, dan ketahanan. (4) Aktifitas fisik yang diperlukan, masa adolesensi merupakan masa yang baik untuk meningkatkan pertumbuhan ukuran tubuh, kemampuan fisik, dan penyempurnaan keterampilan gerak melalui kegiatan olahraga. Olahraga yang dapat dilakukan dapat berupa olahraga perorangan, berpasangan, dan beregu.

Fase dalam belajar gerak agar dapat terampil menurut Singer (1982:9) mengatakan bahwa "(a) Cognitve phase, (b) associative phase, (c) autonomus". Fase-fase tersebut menggambarkan proses penguasaan keterampilan tertentu dan tidak didasarkan pada tingkatan umur melainkan pada tingkatan keterampilan seseorang dalam memecahkan atau melaksanakan gerak yang dilakukan.

Tahapan belajar gerak menurut Fitts dan Posner yang dikutip dalam Richard A. Magill (1993:59-60) adalah sebagai berikut: (a) Tahapan belajar gerak yang pertama yaitu fase kognitif, pada tahap ini ditandai dengan sejumlah besar kesalahan dalam prestasi dan kesalahan yang dilakukan cenderung menjadi besar. (b) Tahap kedua yaitu fase asosiasi, pada tahap ini mengkarakterisasikan perubahan tahap kognitif. Selama tahap asosiasi, banyak fundamental-fundamental dasar atau mekanika dari keterampilan yang mempunyai banyak perluasan yang telah dipelajari. Kesalahan-kesalahan lebih sedikit dan para pelajar berkonsentrasi pada penghalusan keterampilannya. Pada tahap ini terjadi pengembangan sebuah kemampuan untuk mendeteksi beberapa dari kesalahan dalam melaksanakan tugas. Sementara kemampuan untuk melokalisir kesalahan-kesalahan terjadi belum sempurna, sehingga perlu adanya bimbingan khusus tentang bagaimana melanjutkan praktek. Pada tahap ini keberagaman prestasi dari satu usaha ke usaha lain sudah mulai berkurang. (c) Tahap ketiga yaitu fase otonom, pada tahap ini terjadi sesudah banyak praktek dan pengalaman dengan keterampilan. Tahap ini akan bergerak ke tahap akhir dari belajar, tahap kemandirian. Pada tahap ini keterampilan hampir otomatis, artinya individu tidak harus mengikuti keseluruhan produksi dari keterampilan tetapi telah belajar melakukan kebanyakan dari keterampilan tanpa memikirkan sama sekali. Dalam tahap kemandirian pelakupelaku yang terampil mampu tidak hanya mendeteksi kesalahan-kesalahan mereka sendiri tetapi juga membuat penyesuaian yang baik untuk mengkoreksinya. Dalam tahap ini keberagaman prestasi dari hari ke hari telah menjadi sangat kecil. Tahap kemandirian adalah hasil dari jumlah praktek yang hebat sekali, hal ini menjadikan para pelaku menghasilkan respon tanpa berkonsentrasi pada seluruh 
pergerakan. Oleh karena itu mereka dapat menghadirkan aspek-aspek lain yang akan menjadikan prestasi yang optimal.

Membahas mengenai pembelajaran gerak keterampilan tentunya tidak terlepas dari gerak voluntern dan involunter.gerak volunter adalah gerakan yang disertai dengan kesadaran dan kewaspadaan penuh mengenai apa yang sedang dikerjakan serta mencurahkan perhatian pada gerak yang dilakukan atau pada tujuan gerak (Santoso, 2012:292). Gerak involunter adalah gerak-gerakan yang tidak memiliki ciri-ciri seperti pada gerak volunter. Gerak involunter sering disebut gerak tidak sadar, gerak otomatis atau gerak reflek. Gerak volunter dan involunter hampir setiap hari perilaku yang dilakukan melibatkan dua gerak tersebut, dan antara keduanya sulit dipilah. Jadi sesungguhnya tida ada gerak motoris yang murni volunter atau involunter. Semakin sering suatu gerakan dilakukan atau dilatih, maka gerak itu akan semakin sedikit melibatkan gerak volunter, artinya gerakan menjadi semakin seperti refleks, dan gerakan seperti itu disebut gerak refleks bersyarat (conditioned refleks), oleh karena syaratnya telah dipenuhi yaitu berupa latihan. Di dalam dunia kepelatihan, suatu gerakan yang demikian disebut sebagai gerakan otomatis (Santoso, 2012: 292).

Penguasaan keterampilan gerak kecabangan olahraga hanya dapat dicapai melalui proses pembelajaran dan pelatihan, yaitu mempelajari dan memahami pola rumusan geraknya. Selanjutnya harus diikuti dengan pelatihan, yaitu dengan mengulang, mengulang, dan mengulang (drilling) gerakan yang harus dikuasi tersebut. Syarat mutlak yang tidak boleh dilanggar dalam pelatihan teknik adalah: (1) latihan teknik tidak boleh sampai lelah, (2) latihan teknik tidak boleh diberikan kepada atlet yang sudah lelah (Santoso, 2012: 314).

\section{METODE PENELITIAN}

Metode penelitian yang digunakan adalah metode penelitian eksperimen dengan desain penelitian one group pretest and post-test design. Observasi yang dilakukan sebelum eksperimen $\left(\mathrm{Q}_{1}\right)$ disebut pre-test, dan observasi sesudah eksperimen $\left(\mathrm{Q}_{2}\right)$ disebut post-test (Nasir, 2011:175).

Populasi merupakan subyek yang berada pada suatu wilayah dan memnuhi syarat-syarat tertentu berkaitan dengan masalah atau objek penelitian (Supardi, 2016:25). Populasi pada penelitian ini adalah pemain bola basket putera usia SMP pada sekolah basket Smiling Java Boyolali. Populasi yang ada berjumlah 20 orang pemain. Sampel adalah bagian ari populasi yang mempunyai ciri-ciri atau keadaan tertentu yang akan diteliti (Supardi, 2016:26). Sampel pada penelitian ini adalah pemain bola basket yang tergabung dalam sekolah basket Smiling Java putra usia SMP, jadi teknik pengambilan sampel menggunakan total sampling. Jadi sampel yang diambil berjumlah 20 orang.

Teknik analisis data yang digunakan dalam penelitian ini menggunakan uji-t. Analisis yang dilakukan adalah membandingkan data sebelum dan sesudah perlakuan dari satu kelompok sampel, dengan rumus sebagai berikut:

$$
\begin{aligned}
& \mathrm{M} d=\frac{\sum d}{n} \\
& t=\frac{M d}{\sqrt{\frac{\sum x^{2} d}{n(n-1)}}}
\end{aligned}
$$

Keterangan: $d_{i}=$ selisih skor sesudah dengan skor sebelum dari tiap subjek (i); $\mathrm{M}_{\mathrm{d}}=$ rerata dari gain $(\mathrm{d}) ; \mathrm{X}_{\mathrm{d}}=$ deviasi skor gain terhadap reratanya $\left(\mathrm{x}_{\mathrm{d}}=\mathrm{d}_{\mathrm{i}}-\mathrm{M}_{\mathrm{d}}\right) ; \mathrm{X}_{\mathrm{d}}{ }^{2}$ $=$ kuadrat deviasi skor gain terhadap reratanya; $\mathrm{n}$ = banyaknya sampel (subjek penelitian).

Hipotesis:

$\mathrm{H}_{0}: \mu_{\mathrm{A}}=\mu_{\mathrm{B}}$

$\mathrm{H}_{0}: \mu_{\mathrm{A}}=\mu_{\mathrm{B}}$

$\mu_{\mathrm{A}}=$ rerata data sesudah treatment

$\mu_{\mathrm{A}}=$ rerata data sebelum treatment 
Pengujian hipotesis untuk selanjutnya nilai $\mathrm{t}$ ( $\left.\mathrm{t}_{\text {hitung }}\right)$ di atas dibandingkan dengan nilai-t dari tabel distribusi $t \quad\left(t_{\text {tabel }}\right)$. Penentuan nilai $t_{\text {tabel }}$ didasarkan pada taraf signifikansi $\alpha=0,05$ dan $\mathrm{dk}=\mathrm{n}-1$. Kriteria pengujian hipotesis sebagai beriku:

$\mathrm{H}_{0}$ ditolak, jika $\mathrm{t}_{\text {hitung }}>\mathrm{t}_{\text {tabel }}$

$\mathrm{H}_{0}$ diterima, jika $\mathrm{t}_{\text {hitung }}<\mathrm{t}_{\text {tabel }}$

\section{HASIL DAN PEMBAHASAN}

Hasil pre-test dan post-test dimasukan ke dalam tabel 1 di bawah ini. Pembuatan tabel tersebut bertujuan untuk membantu atau mempermudah penghitungan uji beda rata-rata dua kelompok berpasangan $\left(\mathrm{d}-\mathrm{M}_{\mathrm{d}}\right)$.

Tabel 1. Hasil Pretest dan Posttest

\begin{tabular}{cccccc}
\hline \multirow{2}{*}{ No } & \multicolumn{2}{c}{ Skor } & Gain $(\boldsymbol{d})$ & $\begin{array}{c}\boldsymbol{X} \boldsymbol{d} \\
(\boldsymbol{Y} \text { - })\end{array}$ & \multirow{2}{*}{$\boldsymbol{X} \boldsymbol{d}^{2}$} \\
\hline 1 & 11 & 16 & 5 & 1,1 & 1,21 \\
\hline 2 & 9 & 15 & 6 & 2,1 & 4,41 \\
\hline 3 & 9 & 12 & 3 & -0.9 & 0,81 \\
\hline 4 & 12 & 16 & 4 & 0,1 & 0,01 \\
\hline 5 & 9 & 14 & 5 & 1,1 & 1,21 \\
\hline 6 & 7 & 11 & 4 & 0,1 & 0,01 \\
\hline 7 & 12 & 16 & 4 & 0,1 & 0,01 \\
\hline 8 & 8 & 13 & 5 & 1,1 & 1,21 \\
\hline 9 & 7 & 11 & 4 & 0,1 & 0,01 \\
\hline 10 & 11 & 16 & 5 & 1,1 & 1,1 \\
\hline 11 & 10 & 12 & 2 & $-1,9$ & 3,61 \\
\hline 12 & 9 & 14 & 5 & 1,1 & 1,21 \\
\hline 13 & 12 & 15 & 3 & $-0,9$ & 0,81 \\
\hline 14 & 8 & 11 & 3 & $-0,9$ & 0,81 \\
\hline 15 & 13 & 16 & 3 & $-0,9$ & 0,81 \\
\hline 16 & 9 & 14 & 5 & 1,1 & 1,21 \\
\hline 17 & 7 & 12 & 3 & $-0,9$ & 0,81 \\
\hline 18 & 12 & 15 & 3 & $-0,9$ & 0,81 \\
\hline 19 & 8 & 10 & 2 & 1,9 & 3,61 \\
\hline 20 & 9 & 13 & 4 & 0,1 & 0,01 \\
\hline Jumlah & - & $\mathbf{7 8}$ & - & $\mathbf{2 3 , 6 9}$ \\
\hline Rata-Rata & - & $\mathbf{3 , 9}$ & - & - \\
\hline & & & & &
\end{tabular}

Berdasarkan analisis data, hasil dari $t_{\text {hitung }}$ adalah 16,25 . Taraf signifikansi $\alpha=0,05 \mathrm{dan} \mathrm{dk}=19$, maka diperoleh $\mathrm{t}_{\text {tabel }}$ adalah 2,09. Karena $t_{\text {hitung }}>t_{\text {tabel, }}$ yaitu $16,25>2,09$ maka $\mathrm{H}_{0}$ diterima. Berdasarkan analisis data, diketahui adanya peningkatan hasil lay up pada pemain bola basket putra usia SMP yang mengikuti Smiling Java Basket Ball School. Latihan merupakan proses yang dilakukan secara bertahap serta dilakukan berulang-ulang sehingga peserta latihan dapat memahami setiap tahap dan prosesnya sehingga gerakan yang ingin dilakukan dapat diaplikasikan sesuai teknik yang benar. Gerakan lay up yang dibagi menjadi 6 tahap memungkinkan peserta untuk memahami setiap tahapan gerakan lay up. Setiap tahap yang dilakukan berulang-ulang membuat peserta menghafal gerakan yang dilatih. Peningkatan gerakan yang dilakukan secara bertahap dapat membantu kesiapan perserta untuk melakukan gerakan 
berikutnya yang lebuh sulit. Latihan dengan metode tersebut disebut dengan metode latihan part and whole.

Metode latihan part and whole yang diterapkan dalam latihan lay up untuk pemain basket putra usia SMP dinilai sesuai dengan karakteristik pertumbuhan dan perkembangan. Pemain bola basket usia SMP yang berada fase adolesensi memungkinkan terjadinya perkembangan yang cukup pesat apabila gerak keterampilannya dilatih dengan benar. Kunci latihan gerak keterampilan tidak boleh dilakukan terlalu melelahkan seperti latihan kondisi fisik. sehingga perlu dipisah antara latihan gerak keterampilan dan latihan kemampuan kondisi fisik.

\section{KESIMPULAN}

Berdasarkan hasil analisis data dapat disimpulkan, latihan lay up 6 tahap berpengaruh terhadap hasil hasil lay up pemain bola basket putera usia SMP pada sekolah basket Smiling Java Boyolali. Hasil analisis data menunjukan rata-rata peningkatan hasil lay up 3,9. Kemudian di analisis menggunakan uji-t. Hasil dari uji-t menunjukan $t_{\text {hitung }}>t_{\text {tabel }}$ yaitu $16,25>$ 2,09 maka $\mathrm{H}_{0}$ diterima. Peningkatan terjadi karena latihan yang dilakukan secara berulang-ulang dan bertahap untuk menguasai keterampilan lay up. Latihan lay up yang dibagi menjadi 6 tahap membuat pemain lebih paham serta menguasai teknik gerakan lay up. Pemaian usia SMP yang berada pada masa adolesensi yang merupakan fase pertumbuhan dan perkembangan juga menjadi faktor yang mendukung penguasaan suatu gerak keterampilan cabang olahraga.

\section{DAFTAR PUSTAKA}

Firdaus, H., \& Hidayah, T. (2014). Perbandingan metode pembelajaran bagian (part-method) dan metode pembelajaran keseluruhan (wholemethod) terhadap kemampuan siswa dalam melakukan smash bola voli (studi pada kegiatan ekstrakulikuler di SMA Negeri 1

Kamal). Jurnal Pendidikan Olahraga Dan Kesehatan. 2 (2).

Giriwijoyo, S. \& Didik Z.S. (2012). Ilmu faal olahraga (fisiologi olahraga). Bandung: PT Remaja Rosdakarya.

Kosasih, D. (2008). Fundamental basketball. Semarang: Karangturi Media, Yayasan Pendidikan Nasional Karangturi.

Lankor. (2007). Teori kepelatihan dasar (materi untuk kepelatihan dasar). Jakarta.

Magil, R.A. (1993). Motor learning: concepts and aplications. ( $4^{\text {th }} e d$.). Madison: Brown \& Benchmark Publishers.

Nasir, dkk. (2011). Metodologi penulisan kesehatan. Yogyakarta: Nuha Medika.

Sajoto, M. (1995). Peningkatan \& pembinaan kekuatan kondisi fisik dalam olahraga. Jalarta: Dahara Prize.

Singer, R.N. (1980). Motor learning and human performance an application to physical education skill. New York: Mac Milan Publishing Company Inc.

Sodikun, I. (1992). Olahraga pilihan bola basket. Jakarta: Departemen Pendidikan dan Kebudayaan.

Supardi. (2016). Aplikasi statistika dalam penelitian (konsep statistika yang lebih komprehensif. Jakarta: Change Publication.

Wissel, H. (2000). Bola basket dilengkapi dengan program pemahiran teknik dan taktik. Jakarta: PT. Raja Grafindo Persada. 